Sustainable Development in Nasser Lake using the

\title{
Sustainable Development in Nasser Lake using the Integration of Multi-Temporal Remote Sensing Imagery and GIS
}

\author{
Soha A. Mohamed ${ }^{1}$ and Ismail Youssef ${ }^{2}$ \\ 1. igsr.soha.ahmed@alexu.edu.eg \\ The Higher Institute of Tourism, Hotels, and Computer (H.I.T.H.C.) \\ The Ministry of Higher Education and Scientific Research (MHESR), Egypt \\ 2 youssefegyptgeo@hotmail.com \\ Faculty of Art, Menofia University
}

\begin{abstract}
Water is considered one of the most essential elements for life on the earth. Egypt is one of the countries in the world suffering from the water shortage because of the global temperatures increase, decreased precipitation levels due to the climate changes. Furthermore, the misuse of water resources and inefficient irrigation techniques are additional factors worsen the water security in Egypt. Nasser Lake was created as a result of the construction of the Aswan High Dam (AHD) in 1960s to control flooding, store the increased water and produce hydroelectricity. The objective of this research was to monitor and detect the changes in Nasser Lake using integrated techniques of satellite images and GIS. Two Landsat images acquired in 2000 and $201^{9}$ are used to investigate land cover changes in the lake and its surroundings. The findings indicated that Nasser's Lake total area decreased from $5887.7 \mathrm{~km}^{2}$ in 2000 to about $5364.4 \mathrm{~km}^{2}$ in 2019 . Five classes are obtained from classifying satellite images, namely: deep, shallow water, bare soil from type 1 and 2 in addition to quarries. Post classification change detection showed that deep water was $5485.4 \mathrm{~km}^{2}$ in 2000 and decreased to be $4490.9 \mathrm{~km}^{2}$ in 2019 . The shallow water increased from $402.4 \mathrm{~km}^{2}$ in 2000 to $573.5 \mathrm{~km}^{2}$ in 2019 . Markov chains is applied to predict and simulate the future land cover changes from 2019 to 2050 to safeguard against the adverse effects and negative consequences of land cover changes and consequently achieve goals of sustainable development
\end{abstract}

Keywords: Land cover, remote sensing, GIS, image classification, post classification, change detection, Markov chains. 


\section{1.}

\section{Soha A. Mohamed ${ }^{1}$ and Ismail Youssef ${ }^{2}$}

\section{ntroduction}

Freshwater is one of the most important natural resources in the world as life and developmental activities are based water. In addition, accurate information about land cover data is essential for planning, land resources management and decision making (Mohamed, 2019; Mohamed and El-Raey, 2018). Egypt's total area is 1.1 million $\mathrm{km}^{2}$ where desert constitutes $90 \%$ and only $10 \%$ of the total area is inhabited and cultivated. The total population nearly reached 92,115,689 million (CAPMAS, 2017) with an annual growth rate of $1.9 \%$ according to the recent statistics. The increased population growth affects negatively the water supply and increases the water demand for drinking, irrigation, agricultural purposes and industrial development (Ahmed, 2018). Egypt is considered as an extremely arid country with annual rainfall under $200 \mathrm{~mm}$, which decreases rapidly to be zero in the south of Cairo (Elba, 2014). Currently, Egypt is standing below the level of water poverty and suffering from water scarcity. There are major factors affecting Egypt's water security such as the increase in global temperatures and decreased precipitation levels due to climate changes (Elsaeed 2011). Climate changes and its consequences of heat waves, as well as the dry climate of Egypt, increase a significant loss of water due to evaporation in Nasser's Lake which considered the second world's largest man-made lake formed because of the construction of Aswan High Dam (Mohamed and El-Raey, 2018; Hassan 2013).

The Nile River is the main source of fresh water in Egypt (Abdin and Gaafar, 2008) which provides about $95 \%$ of fresh water supplies given that $95 \%$ of the Egyptian population lives within a ten-mile radius of the Nile River. The Nile River basin covers 11 African countries, the upstream countries, and downstream countries (Al-Labbad, 2013). Nile basin countries are facing mainly rapid population growth and economic changing, strong socio-economic dependency on the water with the absence of water management which leads to increasing demand of water and energy (Ibrahim, 2017). Egypt's share of water from the Nile River is about 55.5 billion $\mathrm{m}^{3} /$ year. The agriculture sector consumes about $85.6 \%$ of the Nile water (El Agroudy et al, 2014).

\section{Study area}

Nasser Lake represents the second world's largest man-made lake formed as a result of construction of Aswan High Dam (Ghobrial, 2008; Hala, 2011) extending from the northern part of Sudan to the southern part 
Sustainable Development in Nasser Lake using the

of Egypt between latitudes $21^{\circ} 00^{\prime} 00^{\prime \prime}, 23^{\circ} 46^{\prime} 44^{\prime \prime} \mathrm{N}$, and longitudes $30^{\circ}$ $34^{\prime} 10^{\prime}, 33^{\circ} 28^{\prime} 18^{\prime \prime}$ E (Hamed, 2017) as illustrate in Figure 1. The surface area of Nasser Lake is about $5200 \mathrm{~km}^{2}$ with a maximum capacity of 165 $\mathrm{km}^{3}$ and mean depth of 25 meters; its surface elevation is 175 meters. The lake is circa $550 \mathrm{~km}$ long more than $350 \mathrm{~km}$ in Egypt and the rest in Sudan (Kim and Sultan, 2002; Ball, 1927; Dasco, 1998). Nasser Lake represents the national freshwater bank of Egypt (Abd-Ellah, 2016) and plays an important role in the local and national economy (Mostafaa and Soussa, 2010; El-Shabrawy, 2009).

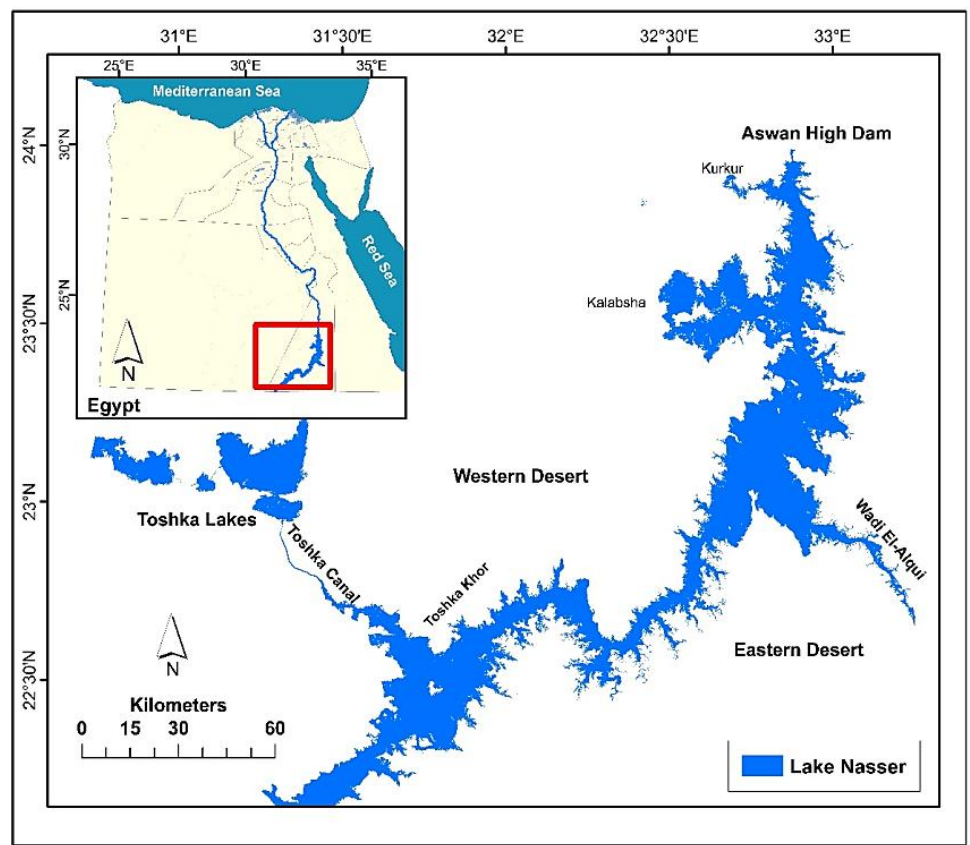

Figure 1. Location map for Nasser Lake in Aswan Governorate, Egypt

Nasser Lake is located in a desert area with very low precipitation and extremely high evaporation levels. The water loss due to the evaporation ranges between 10 to 16 billion $\mathrm{m}^{3}$ per year, this is equivalent to (20-30\%) of the Egyptian budget from Nile water (Shaltout, 1997). Maximum water levels in Nasser Lake have differed from about 160 meters to 183 meters (El-Gammal et al., 2010). Halls et al., (2016) stated that during the past decade, maximum water levels have remained above 170 meters, fluctuating by about $1-2 \mathrm{~m} / \mathrm{yr}$. Water levels are classified into three categories: (i) dead water level ( $<150$ meters above mean sea level), which is the minimum level required for operating the High Dam hydroelectric 


\section{Soha A. Mohamed ${ }^{1}$ and Ismail Youssef ${ }^{2}$}

power station; (ii) live water level (150-175 meters); and (iii) flood-control water level (175-183 meters). The Egypt government has taken some important measures and ministerial decrees were issued to protect the lake from pollution due to human activities. Decree 203/2002 identified a $2 \mathrm{~km}$ buffer zone around, where it is not allowed to have any industrial, agricultural and tourist activities. Therefore, the quality of water is enhanced and the threats of environmental degradation due to regional sources are faced (Zaghloul et al., 2011).

\section{Materials and Methods}

Two data sources are used to accomplish the objectives of the study including topographic maps and satellite images. Topographic maps of scale 1:50000 obtained from the General Egyptian Survey Authority produced in 1990. Two Landsat images have been downloaded freely from http://earthexplorer.usgs.gov and acquired in 2000 and 2019 as shown in Figure 2.
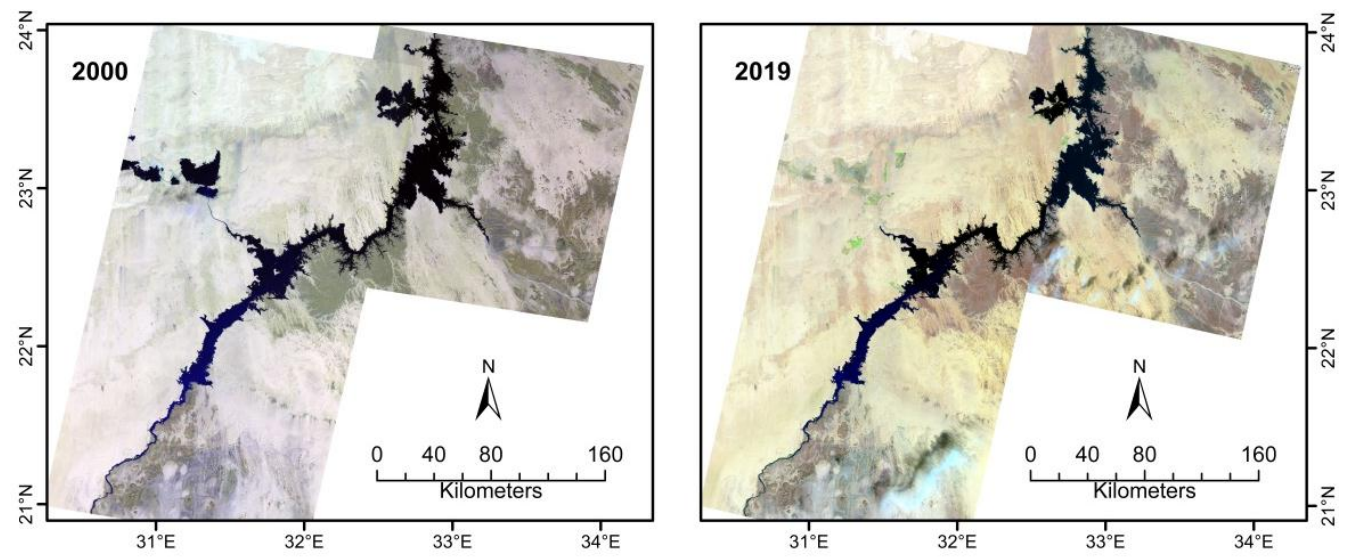

Figure 2. Landsat images for Nasser Lake, Egypt

The spatial resolution of the acquired images was 30 meters, so panchromatic band is fused with multispectral bands to enable good visual analysis, with the spatial resolution 15 meters. The study area was covered with three scenes, which were geometrically corrected and registered to the UTM coordinate system, zone 36N; datum name WGS84. Figure 3 shows the flowchart methodology: 
Sustainable Development in Nasser Lake using the-

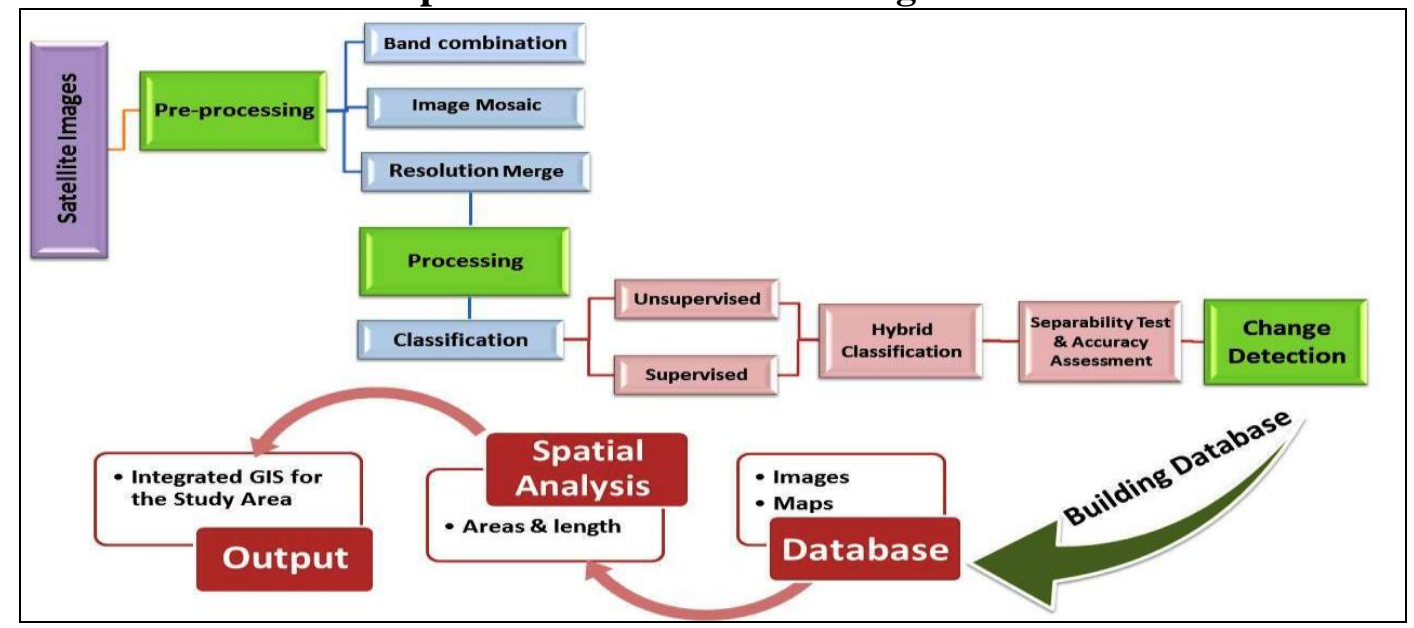

Figure 3. Methodology flowchart

The methodology can be summarized in the following steps:

1. Image preprocessing included layer stacking (band combination), image mosaic (as study area was covered by three scenes), and resolution merge to merge multispectral (30 meters) with a panchromatic spatial resolution (15 meters).

2. Image processing included three steps namely: unsupervised, supervised classification and accuracy assessment. The unsupervised classification was carried out using The Iterative Self-Organizing Data Analysis Technique (ISODATA) to classify the image into 50 clusters. The number of iterations is adjusted as necessary to achieve a $99 \%$ convergence level. As a next step, the supervised classification using a maximum likelihood algorithm was carried out using collected training samples from field visits to represent different land cover features for the study area. The training sample of unreachable locations was identified with the aid of digital globe and google earth. All collected training samples are merged into one file in the polygon form and stored as vector layers. As, a consequent step, the training samples were used to generate a set of signatures for each available land cover cluster. The signatures from unsupervised classification with collected training samples were used as input to the supervised algorithm to perform hybrid classification.

3. The hybrid classification was used to detect changes and generate land cover maps for Nasser Lake in Egypt in the time period from 2000 to 2019. 
4. Accuracy of hybrid classified images was assessed using 500 random points distributed equally in the generated five classes. The accuracy random points were collected from both of field visits, topographic maps, digital globe and google earth.

5. Post-comparison change detection technique is applied to get the change images.

\section{Results and Discussions}

The classification accuracy the Landsat-7 ETM+ 2000 and Landsat8 OLI/TIRS 2019 images were $83.95 \%$ and $85.71 \%$ respectively. It is noticed that many changes occurred in land cover from 2000 to 2019 as seen in Table 1 and Figure 4.

Table 1. Change in land cover classes (2000-2019)

\begin{tabular}{|r|c|c|}
\hline Land Cover & Area (2000) $\mathbf{k m}^{\mathbf{2}}$ & Area (2019) $\mathbf{k m}^{\mathbf{2}}$ \\
\hline Deep water & $5485.34^{*}$ & 4490.9 \\
\hline Shallow water & $402.37^{*}$ & 573.5 \\
\hline $\begin{array}{r}\text { Axial } \\
\text { Vegetation }\end{array}$ & - & 78.8 \\
\hline Bare Soil (1) & 43827.49 & 39597.9 \\
\hline Bare Soil (2) & 11521.74 & 16226.9 \\
\hline Quarries & 5539.99 & 6508.9 \\
\hline Total area & $\mathbf{6 6 7 7 7}$ & $\mathbf{6 6 7 7 7}$ \\
\hline
\end{tabular}

* Water area including both of Nasser Lake, Toshka Lakes, and Toshka canal 
Sustainable Development in Nasser Lake using the

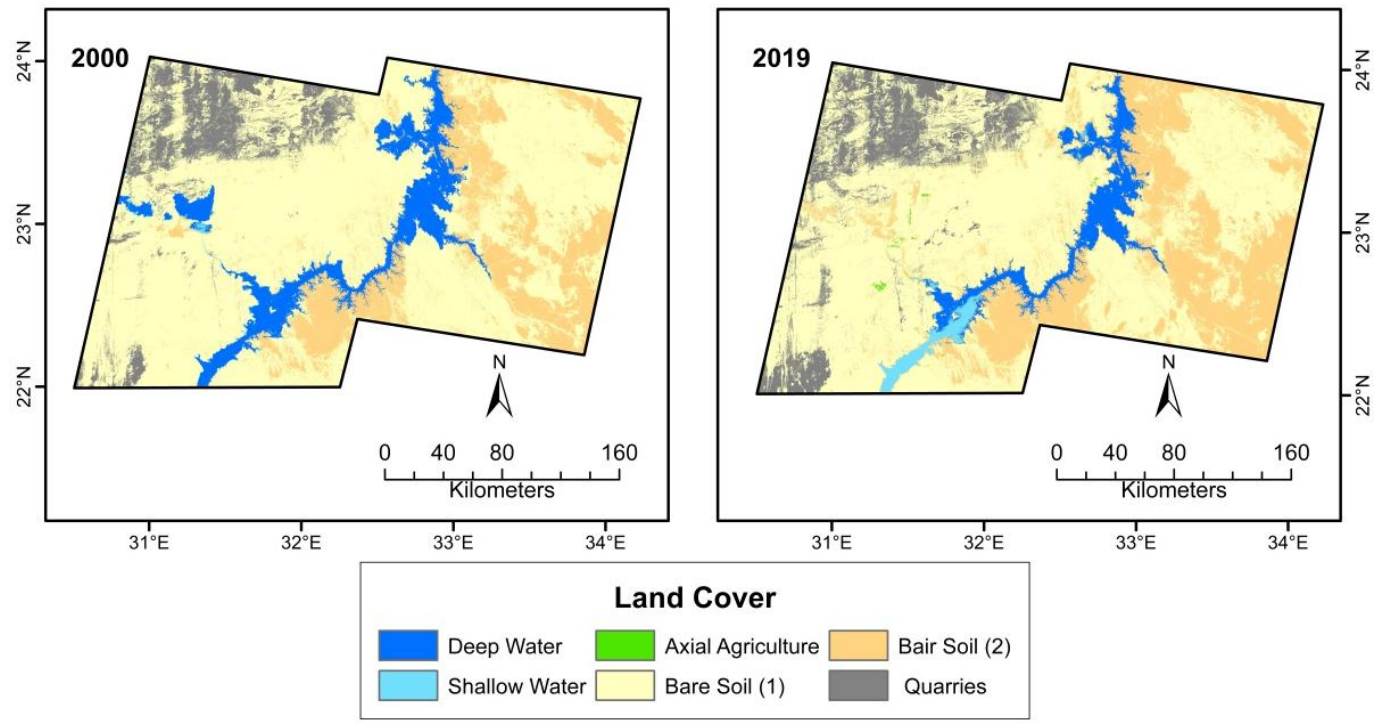

Figure 4. Nasser Lake hybrid image classification

To measure changes in water areas, post classification change detection analysis was carried out. Figure 5 shows the changes in water area classes in the time period from 2000 to 2019. Deep water was about 5485.4 $\mathrm{km}^{2}$ and decreased to $4490.9 \mathrm{~km}^{2}$ with a loss of about $994.5 \mathrm{~km}^{2}$. The decrease concentrated in the southern part of Nasser Lake and in Toshka Lakes which is dried completely in 2019. The Toshka Lakes are converted completely from water body to barren land due to water loss. Shallow water class was increased from $402.4 \mathrm{~km}^{2}$ in 2000 to $573.5 \mathrm{~km}^{2}$ in 2019 . The shallow water appeared in the south of Nasser Lake and in many parts in the Lake. The connecting canal (Toshka Canal) between Nasser Lake and Toshka Lakes is completely dried in the year 2019. 


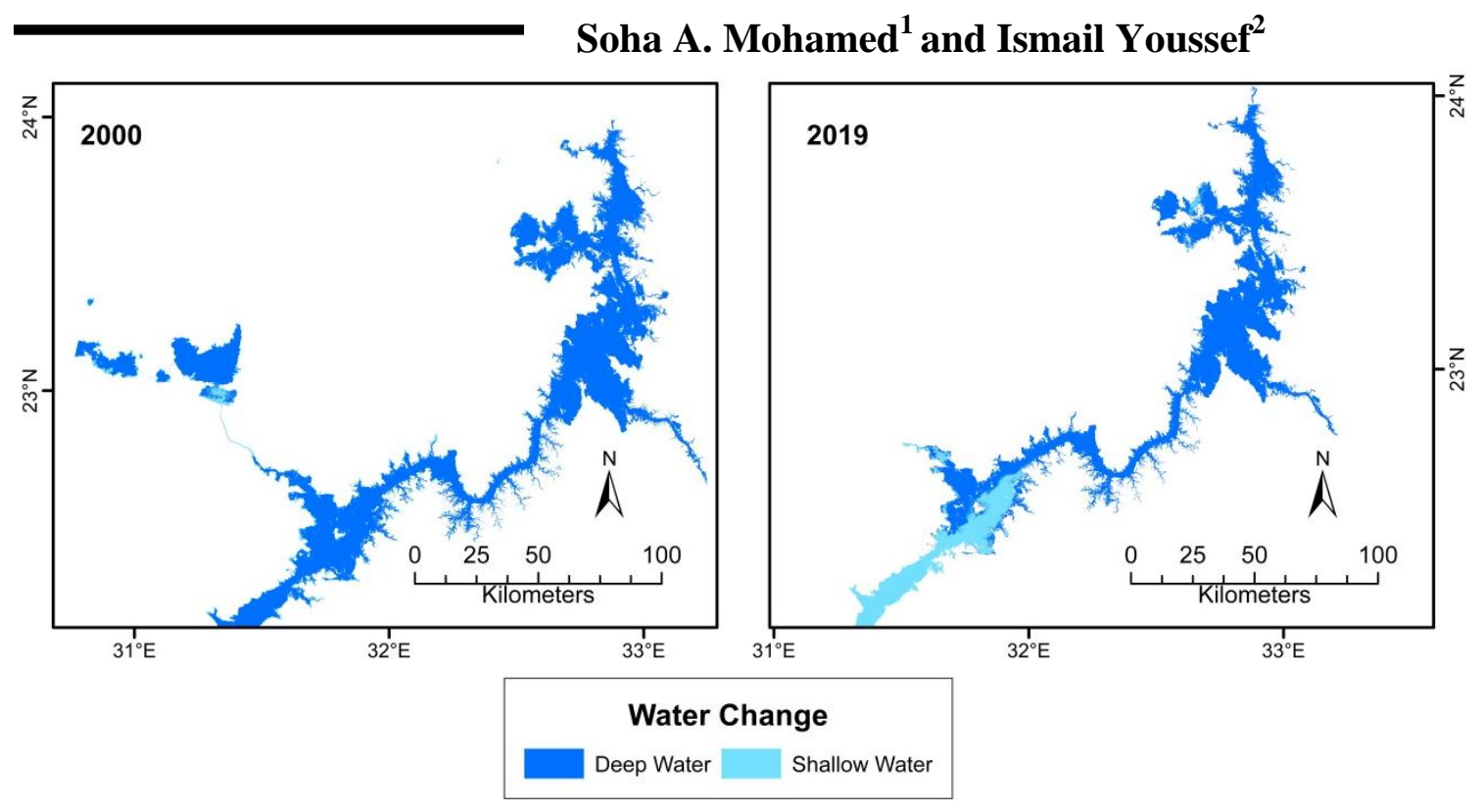

Figure 5. Water change in Nasser Lake

In this study the obtained results are found to be matched with https://global-surface-water.appspot.com website, which presents water occurrence around the world in the time period from 1984 to 2019. Water areas appeared to be permanent are in blue color where lost and disappeared water areas appeared in magenta grades as shown in Figure 6.

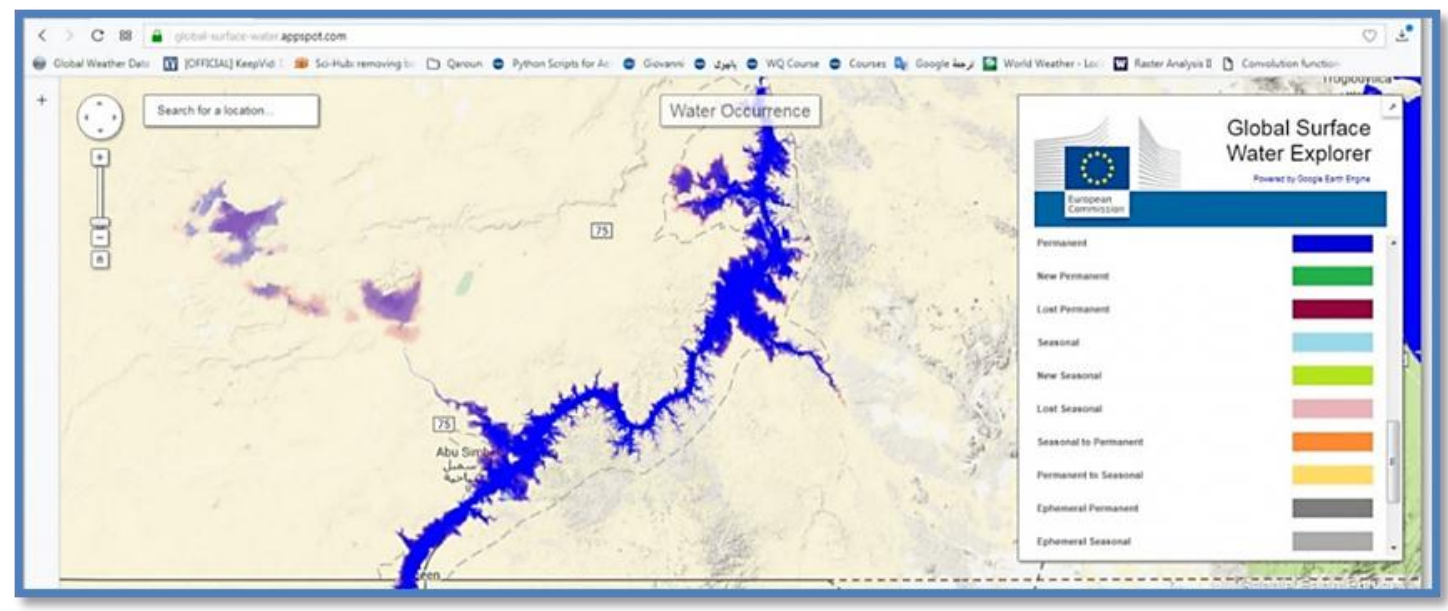

Figure 6. Lake Nasser water occurrence

Source: global-surface-water.appspot.com 


\section{Sustainable Development in Nasser Lake using the}

Modeling of future land cover for Lake Nasser in year 2050 is performed using Markov chains in the Idrisi selva software version 17.00 that was developed by Clark Labs, Clark University. The future land cover in 2050 are based on supervised images of 2000 and. Markov chains yeilds a set of conditional probability images as seen in Figure7.

The results in this study revealed that:

1. The shortage in water will have a dangerous impact in Egypt will be a reduction in power generated at Aswan High Dam when the water levels of Nasser Lake are decreased, the electricity production of the High Dam and Aswan Reservoir Reduce by about 20\%. Water deficit in the river with an average annual income of 10 billion cubic meters on average, the Nile flow into Egypt could be cut by $12-25 \%$ during the filling period.

2. Reduction of the water level in the Nile, canals, and branches will affect negatively on navigational and Nile cruises.

3. The decline of water flow leads to stopping land reclamation projects, agricultural expansion and the end of Toshka project, Al-Salam Canal and El-Hamam Canal in the Northwestern coast.

4. Lack of irrigation water will lead to expansion in the use of agricultural drainage water for irrigation reaching currently about 7 billion $\mathrm{m} 3$ per year, which doubles the salinity 3 times after each irrigation then the water reaches the banks again with higher concentrations in each irrigation, leading to increased water salinity of agricultural lands in the Delta.

5. Increase in seawater intrusion in coastal aquifers in North Delta, affecting groundwater quality and increased salinity in these aquifers Environmental degradation and increasing pollution leading to an imbalance in the natural ecosystem in Egyptian North Lakes due to water shortage.

\section{Conclusions and Recommendations}

Egypt needs innovative plans to conserve and manage the current freshwater resources to face the growing water demand for the booming population growth, irrigate agriculture, and industrial activities. Solving the 


\section{Soha A. Mohamed ${ }^{1}$ and Ismail Youssef ${ }^{\mathbf{2}}$}

water crisis will require coordinated efforts from local, national and international levels. There are several ways to solve the problem such as:

1. Efficient use of water in irrigation techniques to reduce and sustain water consumption and loss.

2. Modify current irrigation systems from surface irrigation to modern sprinkler and drip irrigation.

3. Carry out most of the irrigation at night to reduce evaporation water loss as much as possible.

4. Reuse of drainage water and municipal water after suitable treatment.

5. Carry out and promote desalination of seawater.

6. Importance of international co-operation between the River Nile basin countries.

7. Define a strategy for freshwater conservation support as integrated water management for Nasser Lake to provide decision makers with the status of the Lake.

\section{References}

1. 1- AQUASTAT Programme, (2007): "dams and agriculture in Africa", Water Development and Management Unit (NRLW) Land and Water Division (NRL) Food and Agriculture Organization of the United Nations

(FAO), http://www.fao.org/tempref/agl/AGLW/docs/Aquastat_Dams_Africa_07 0524.pdf.

2. Abdelhady, D., Aggestam, K., Andersson, D., Beckman, O., Berndtsson, R., Palmgren, K., B., Madani, K., Ozkirimli, U., Persson, K., M., and Pilesjö, P., (2015): "The Nile and the Grand Ethiopian Renaissance Dam: Is There a Meeting Point between Nationalism and Hydro solidarity" Universities Council on Water Resources, Journal of Contemporary Water Research and Education, 155: pp 73-82.

3. Abd-Ellah R., El-Geziry T., (2016): "Bathymetric study of some Khors in Lake Nasser, Egypt". Lakes, Reservoirs and Ponds, 10(2): pp 139158, Romanian Limnogeographical Association.

4. Abdin, E., and Gaafar, I., (2008): "Rational water use in Egypt", CIHEAM, $\mathrm{pp}$ 11-27, retrieved from: http://om.ciheam.org/article.php?IDPDF=801177. 
Sustainable Development in Nasser Lake using the

5. Ahmed, S., Selim, N., and El-Raey, M., (2018): "Flash Floods Vulnerability Assessment Using GIS Spatial Modeling and Remote Sensing Data in El-Arish City, North of Sinai, Egypt". The $9^{\text {th }}$ Int. Conf. for Develop. and Env. In the Arab World, Aril 15 - 17: pp 361-373

6. Al-Labbad, M., (2013): "Egypt, Ethiopia Headed for War Over Water". Al-Monitor: The Pulse of the Middle East.

7. Attalla, R. A, (2015): "Grand Ethiopian Renaissance Dam (GERD)". Faculty of Worcester Polytechnic Institute (WPI), IQP-GFS-1504, pp 174.

8. Ball, J., (1927): "Problems of the Libyan desert". The Geographical Journal, 70, 21-38, pp 105-128.

9. CAPMAS (Central Agency for Public Mobilization and Statistics), (2017): "Statistical Year Book of ARE". Arab Republic of Egypt, http://www.capmas.gov.eg

10. Dasco (1998): "Lithology and Casing Details for well". Cairo: Ministry of public works and Water Resources, National Egyptian Drilling and Petroleum Services, No. 3.

11. El-Agroudy, N., Shafiq, F., A., and Mokhtar, S., (2014): "The Impact of Establishing the Ethiopian Dam Renaissance on Egypt", Journal of Basic and Applied Scientific Research, ISSN 2090-4304, pp. 1-5.

12. Elba E., Farghaly D., and Urban B., (2014): "Modeling High Aswan Dam Reservoir Morphology Using Remote Sensing to Reduce Evaporation". International Journal of Geosciences, 5: pp 156-169.

13. El-Gammal, E., A., Salem, S., M., and El Gammal, A., A., (2010): "Change detection studies on the world's biggest artificial lake (Lake Nasser, Egypt)". The Egyptian Journal of Remote Sensing and Space Sciences, 13, pp 89-99.

14. El-Shabrawy, G., M., (2009): "Lake Nasser-Nubia", H.J. Dumont (ed.), The Nile: Origin, Environments, Limnology and Human Use, (C) Springer Science, Business Media B.V., pp 125-155.

15. FAO, (2016): "Geo-referenced database on dams in Africa Notes and References", http://www.fao.org/nr/water/aquastat/dams/index.stm.

16. Ghobrial, M., (2008): "River Nile, History, Present and Future Prosperity". National Institute of Oceanography and Fisheries, Alexandria, Egypt.

17. Hala M. E., (2011): "Estimation of Evaporation Losses from Lake Nasser using Remote Sensing and GIS RASTER Calculator model". Survey Research Institute, National Water Research Center, pp 1-8. 


\section{Soha A. Mohamed ${ }^{1}$ and Ismail Youssef ${ }^{2}$}

18. Halls, A., Habib, O., A., Nasr-Allah, A., and Dickson, M., (2016): "Lake Nasser Fisheries: literature review and situation analysis". Swiss agency for development and cooperation SDC, pp 1-39.

19. Hamed, M., A., (2017): "Estimation of Water Quality Parameters in Lake Nasser using Remote Sensing techniques". Twentieth International Water Technology Conference, IWTC20, Hurghada, 18-20 May 2017, pp 630-644.

20. Hussen, N., (2017): "Sustainable Development of Lake Maryut using Remote Sensing and GIS technique" Institute of Graduated Studies and Research, Alexandria University.

21. Ibrahim, A., I., R., (2017): "Impact of Ethiopian Renaissance Dam and Population on Future Egypt Water Needs". American Journal of Engineering Research (AJER), e-ISSN: 2320-0847 p-ISSN: 2320-0936, 6(5): pp-160-171.

22. IPoE, (2013): "International Panel of Experts on Grand Ethiopian Renaissance Dam Project (GERDP)", https://www.internationalrivers.org/sites/default/files/attachedfiles/international_panel_of_experts_for_ethiopian_renaissance_damfinal_report_1.pdf.

23. Kim, J., and Sultan, M., (2002): "Assessment of the long-term hydrologic impacts of Lake Nasser and related irrigation projects in southwestern Egypt". Journal of Hydrology, 262: pp 68-83.

24. Mantel, S.K., Hughes, D. A., and Muller, N.W., (2010): " Ecological impacts of small dams on South African rivers Part 1: Drivers of change - water quantity and quality", Water SA Vol. 36 No. 3, ISSN 18167950, Available on website http://www.wrc.org.za

25. Mostafaa, M. M., and Soussa, H. K., (2010): "Monitoring of Lake Nasser using Remote Sensing and GIS Techniques", retrieved from: http://citeseerx.ist.psu.edu/viewdoc/download?doi=10.1.1.638.4417\&rep =rep1\&type $=$ pdf.

26. NBI, (2012): "State of the River Nile Basin Report. Nile Basin Initiative". (NBI) Publishing.

27. Shaltout, M. and El-Hosary, T. N., (1997): "Estimating the evaporation over Nasser lake in the upper Egypt from Meteosat observations". Advances Space Research, 19: pp 515-518.

28. Siciliano, G., and Urban, F., (2016): " Hydropower development and natural resource allocation between competing users and uses: evidence from Southeast Asia and Africa", Global governance/politics, climate justice \& agrarian/social justice: linkages and challenges, an international colloquium, 
Sustainable Development in Nasser Lake using the

https://www.iss.nl/sites/corporate/files/49ICAS_CP_Siciliano_and_Urba n.pdf.

29. Soliman, G., Soussa, H., and El-Sayed, S., (2016): "Assessment of Grand Ethiopian Renaissance Dam impacts using Decision Support System". Journal of Computer Engineering (IOSR-JCE), 18(5), pp 0818.

30. Tesfa, B., C., (2013): "Benefit of Grand Ethiopian Renaissance Dam Project (GERDP) for Sudan and Egypt", EIPSA Communicating Article, 1(1): pp1-12.

31. World Commission on Dams, (2000): " Dams and Development: A New Framework for Decision-Making" http://www.rivernet.org/general/wcd/wcd_overview_english.pdf.

32. Zaghloul, S., S., Pacini, N., Schwaiger, K., and Henry, P., (2011): "Towards a Lake Nasser Management Plan: Results of a Pilot test on Integrated Water Resources Management, Fifteenth International Water Technology Conference, IWTC-15, Alexandria, Egypt, pp 1-13.

33. Soha A. Mohamed: "Application of satellite image processing and GIS-Spatial modeling for mapping urban areas prone to flash floods in Qena governorate, Egypt". Journal of African Earth $\begin{array}{lll}\text { Sciences, } & \text { Vol. } & \text { 2019, }\end{array}$ https://doi.org/10.1016/j.jafrearsci.2019.05.015.

34. Soha A. Mohamed and Mohamed E. El-Raey: "Vulnerability Parameters for Flash Floods Using GIS Spatial Modeling and Remotely Sensed Data in El-Arish City, North of Sinai-Egypt". Nat. Hazards, 2019. https://doi.org/10.1007/s11069-019-03571-X. 